\title{
TOBIT AND JUDITH
}

\author{
by B Otzen ${ }^{1}$
}

London: Sheffield Academic Press

2002

p. xii +162

ISBN 0826460534

\section{Reviewed by Werner Lategan}

This publication forms part of the Guides to Apocrypha and Pseudepigrapha series and provides an excellent introduction to the books of Tobit and Judith. Otzen addresses the problem of relating real history to historical fiction. He examines the genres and purposes of each, and explores the literary and religious motives of the two stories (interesting to note is his discussion of the Achikar motif (and wisdom teaching) in Tobit (24-26) and the theme of sexuality and death in the book of Judith (109-113)). His discussion of textual problems or textual versions (the Greek texts of the LXX vs. the Hebrew-Aramaic fragments from Qumran) adds to the value of this publication. Questions regarding authorship and date are also addressed. Further, the canonical position or status of both books is also addressed. Throughout this publication the reader is exposed to a variety of approaches followed in the interpretation of the two books, providing the reader with a feel for the Wirkung of these texts in different reading communities (scholarly and otherwise).

Otzen views the books of Tobit and Judith as Jewish legends (in terms of genre and style), possibly created in the $3^{\text {rd }}$ or $2^{\text {nd }}$ century BCE. Tobit originating in the Eastern Diaspora and Judith in Palestine. What both books seem to have in common is their narrative setting in the $7^{\text {th }}$ century BCE under the Assyrian empire, which brings one to the question of the relation between historiography and historical fiction.

In his discussion of the genre of the two books, Otzen defines legend as a short story with a rather loose relation to history and reality but at the same time with its centre of gravity in religious edification (p. 127). For him, Tobit fits this description of legend, while the book of Judith is defined as a short story. According to Otzen's definition of a short story the action of the short story is mostly concentrated on a particular event and reaches, within a comparatively short span of time, its apex in a decisive dilemma and turning point in contradistinction to the novel with its long, perhaps life-long chain of events (p. 126). Since Judith is concentrated on a single event, namely the murder of Holofernes, Otzen regards it as a short story. However, the question concerning the genre of the two books remains open for discussion.

In chapter three the reader finds a very interesting discussion of the development of the book of Tobit. The question is raised whether the present form of the story should be seen as a revision of an earlier version, or rather as based on other folklore in the surrounding area. Can one speak of or identify a movement from a so-called international fairy-tale to the present story in Tobit? In this regard he refers to the work of the Finish school of comparative methodology, identifying a so-called "grateful dead" or "dead helper" archetypal fairy-tale in different cultures. It could also be asked whether Tobit developed from a Jewish fairy-tale ( $\mathrm{p} \mathrm{15)}$ into a Jewish legend ( $\mathrm{p}$ 16). For Otzen the book of Tobit is

1. Benedict Otzen is Professor of Old Testament Exegesis at the University of Aarhus, Denmark. 
not just an entertaining fairy-tale but a legend, an edifying and didactic narrative, told among the Jews in the Diaspora. The concern of this legend would be the reward for those faithful to the Law of Moses, trusting in Providence. There are some interesting similarities between the book of Tobit and other Old Testament stories and figures (e.g. Jacob, Saul, David, Jonah). But for Otzen the period colour of the book of Tobit is different to such a degree that the distance from the well-known biblical stories appears great. Thus, the reader should be careful not to draw direct parallels too hastily. Concerning the development of the book of Judith, Otzen regards it as part of the narratives called 'rescuestories' - concerning persons who come forward in critical situations and save the chosen people (p. 68). Moses can be viewed as a prototype of such figures. What makes Judith interesting is that the central figure is a woman, but of course this is not strange or foreign to the biblical tradition. For Otzen, the book of Judith must be placed at the point where two strong biblical traditions meet, namely the tradition of the salvation of the chosen people and the tradition of the clever and heroic woman (p. 69). Otzen places the possible development of the two stories in perspective and incorporates a number of divergent viewpoints in his discussion. This also indicates to the reader that there still remains a lot of work to be done on the subject.

As an introductory work Otzen's publication serves it purpose well. In traditions were the Apocrypha was or is not (traditionally) considered as part of the canon, it could be interesting to note that Reformers like Luther and Calvin paid close attention to the books of Tobit and Judith. Perhaps it could be advantages if these stories are re-introduced or rediscovered within such traditions. In this regard Otzen's critical discussion of the most important scholarship regarding the books of Tobit and Judith will be very helpful to those unfamiliar with these two apocryphal writings. In addition, it also serves as an important reminder that the potential of these stories (within different reading communities) should not be underestimated. 